\title{
Mobilization Networks and the Outcomes of Neighborhood Protests in Ankara
}

\author{
Ankara Mahallelerinde Mobilizasyon Ağları ve Protesto Sonuçları
}

\begin{abstract}
Güneş ERTAN
Asst. Prof., Koç University, College of Administrative Sciences and Economics, International Relations Department, İstanbul, Turkey gunesertan@ku.edu.tr

ORCID ID: 0000-0002-7997-6748
\end{abstract}

DOI: $10.5505 /$ jas.2019.92053

\begin{abstract}
This study aims to understand how the structure of mobilization networks relates to the outcomes of collective action by using 17 cases of neighborhood protests in Ankara between 2007-2011. Based on police records and on site interviews, the findings of the study suggest that successful outcomes depend on two mobilization structure related processes; the first one facilitates the efficient flow of information for coordination purposes, while the second increases the tendency of participants to use high-risk disruptive tactics due to the prevalence of strong ties amongst the protagonists. This paper also considers, to some extent, the antecedents of these structures, and shows that they originate from two sources that very much depend on each other: the spatial configuration of the neighborhood in question and pre-existing informal social ties.
\end{abstract}

Keywords: Social networks, Mobilization networks, Collective action, Local protests, Ankara

\section{$\ddot{O} z$}

Çalışma, 2007-2011 arası Ankara'nın çeşitli mahallelerinde gerçekleşen 17 eylemi inceleyerek mobilizasyon ağlarının yapısının yerel protesto olaylarının sonuçlarıyla nasıl ilişkili olduğunu anlamayı amaçlamaktadır. Araştırmanın verileri polis kayıtları ve saha görüşmelerinden oluşmaktadır. Sonuç olarak olumlu sonuç ile ilişkili iki ayrı mekanizma belirlenmiştir. Birinci mekanizma verimli bilgi akışını sağlayarak katılımcıların koordinasyonunu kolaylaştırır. İkincisi ise katılımcıların arasındaki güçlü bağlar nedeniyle riskli taktiklerin kullanılma eğilimini artırır. Mobilizasyon ă̆larının öncülleri olarak mekansal yapılar ve enformel sosyal ağlar göze çarpmaktadır.

Anahtar sözcükler: Sosyal ağlar, Mobilizasyon ağları, Kolektif eylemler, Yerel protestolar, Ankara

\section{Introduction}

There are an increasing number of studies that examine the relationship between collective action and social networks. The most studied aspect of social networks, with regards to collective action, is the determinants of differential participation (e.g. Diani and McAdam, 2003; Passy and Guigni, 2001; Gould, 1995). The principal idea in many of these studies is the fact that individuals do not make decisions in isolation. Instead, the social networks in which they are embedded re-structure the costs and benefits of participation by the dissemination of emotions, ideas, and information, as well as by acting as a source of peer pressure for individuals who are less likely to participate in the absence of social networks (Passy and Guigni, 2001; Diani, 2003; Goodwin and Jas- 
per, 2004; Passy, 2003). However, what is missing in this line of research are studies that go beyond individuallevel analysis to comparatively consider the properties of global network structure.

Many network scholars have recently argued that there is a need for more studies that analyze the outcomes of networks at the global level (Provan, Fish, and Joerg, 2007; Siegel, 2009; Borgatti, Mehra, Brass, and Labianca, 2009). The main motivations behind such calls are that networks come in various forms, and very little is known about how these network structures are associated with the outcomes of collective action at the macro level. It is important to bear in mind that social networks that have similar size and density can still be substantially different from each other.

This paper therefore aims to address this gap in the literature by evaluating the role of neighborhood mobilization structures on protest outcomes within the context of Ankara. The study shows that network structure is associated with successful outcomes as structure either facilitates the efficient flow of information and resources, or it affects the propensity for risky behavior due to the existence of dense structures. It is also seen that these network structures are entangled with other in terms of causal conditions. While there is no single magic bullet network structure that outperforms the others; different network structures are conducive to the achievement of successful outcomes in combination with different causal factors (Gould, 1995; Siegel, 2009).

In the following sections, a review of the socio-historical context of neighborhood protests in Ankara is followed by an examination of the role of network structure in conjunction with other causal conditions. This examination utilizes various theoretical approaches, emphasized by the collective action literature, including political opportunity structure, resource mobilization, and framing approaches.

\section{Contextualization of the Study}

The effect of mobilization structures on collective action outcomes is investigated within the context of Ankara, Turkey. The study consists of 17 cases of neighborhood mobilizations, based on inter-personal networks in Ankara, between June 2006 and June 2011.

Ankara was a relatively small Ottoman town with a population of less than 30,000 when the new Republic decided to make it the capital city of Turkey on October 1923 (Tankut, 1993). As Ankara gained an important position as the new capital of the Republic, it had be appropriately designed and built as an example city of a modern Turkey. This meant that it was felt that it should be similar to European capitals without any references to Ottoman cultural heritage, or the architectural style that had dominated Istanbul (Tankut, 1993; Önge, 2007).

By the early 1950s, technological improvements in agriculture and improved roads and infrastructure had generated large scale migration in Turkey to the cities. The infrastructure and labor markets of the cities were not ready for this unprecedented migration. In Ankara, zoning policies and the gardened town houses created by the Jansen's plan were quickly being overwhelmed by densely populated apartment buildings constructed by small sized developers known as yapsatçı (Tekeli, 1982). Moreover, unable to meet the rising housing demand, authorities condoned the emergence of migrant squatter houses on public land known as gecekondu, meaning built over night. Starting in the early 1980s, large scale housing complexes started to emerge in the western corridor of Ankara following major legal and organizational changes to the national housing policy. During the same period, gecekondu settlements began to be redeveloped into small apartment buildings (Batuman, 2013). Over the years, Ankara became home to a large number of migrant communities, as well as to the new Republic's military, the bureaucratic elite, and the civil servants that were employed in various branches of the central government.

With the rise of neo-liberal policies in the 1980s, local governments in Turkey also went through significant transformations with major increases in their autonomy and resources (Erder and Incioglu, 2008). However, this transformation of the local governments did not translate into advancement of the local democracy (Bayraktar, 2007). In 1984, a new legislation (Law No. 3030) created a two layered municipal government in large cities such as Ankara, Istanbul, and Izmir. With this new law, district based municipalities were preserved, but lost most of their powers and resources with the birth of metropolitan municipalities (Bayraktar, 2007). The structure of municipalities can be seen as being microcosms of national governance structures, in that there is limited transparency and accountability with public participation in the decision making processes being well integrated into the legal framework of operations (Bayraktar, 2018).

These metropolitan municipalities, including Ankara, are mostly characterized by having very powerful mayors. 
In practice, municipal councils have limited power in decision making processes since the mayor is the president of the council and s/he also decides the agenda of the meetings. Furthermore, the members of the council tend to follow the opinions of the mayor when they belong to the same political party, and the composition of the councils fail to represent the diverse social and economic structure of the local citizens (Bayraktar, 2007).

For the period that covers the duration of the cases studied, the local political environment in Ankara was relatively constant in comparison to other cities in Turkey with the same mayor, İ. Melih Gökçek, governing the city between 1994 and 2017. Batuman (2013) describes Gökçek's administration style as a case of pragmatic populism that thrived on conflict with the organizations and universities that opposed his mega projects which usually ignored the environmental costs, as well as the historical and cultural worth of structures and sites from the early republican era. Gökçek's term was overall characterized by an aggressive increase in the outsourcing of municipal services to private companies, without any public surveillance, as well as a lack of public participation in policy processes (Doğan, 2005).

Starting in the early 2000s, there has been a number of policy initiatives to promote the decentralization of urban policy in line with the EU admission process and UN sustainable development goals (Şahin, 2019). Initiatives such as the Urbanization Council and Integrated Urban Development Strategy and Action Plan (KENTGES) aims to make local governance in Turkey more participatory and less hierarchical. However, these attempts have failed to trigger significant change, and the AK Party's top-down and centralized governance approach continues to dominate urban policy (Şahin, 2019).

The district level political environment for the duration of cases has also remained relatively stable. The mayors of district level municipalities did not change during the local elections in 2009, with the exception of Yenimahalle (won by the CHP from the AK Party). At the district level, a number of urban councils were established in the mid2000s to include citizen participation in policy making, however such councils in the districts of Ankara did not function well since most civil society actors were either not invited to meetings, or were not allowed to speak. Some past participants in these councils have stated that lengthy discussions in urban council meetings rarely generated tangible outcomes (interview notes). That said, the larger political opportunity structure in Ankara and its local districts has generally been to some extent consistent between June 2006 and June 2011.

\section{A Closer Look at the Cases}

The study consists of 17 cases of short-lived, and to some extent, spontaneous neighborhood mobilizations. Among these cases, 12 are related to stopping the construction of cellular towers or removing those in place. The remaining five cases involve various issues such as efforts to reverse a decision to change street names, to compel the municipality to rebuild an overpass taken down during road construction, to facilitate the repair of street lights, to obstruct a proposal to build an amusement park, and to prevent the relocation of an inter-city bus stop. Figure 1 shows that twelve of the cases were concentrated in or near the towns of Mamak and Çayyolu, while the remaining five were mostly scattered around the city center.

Çayyolu is a middle-upper class suburban neighborhood in the South-West of Ankara that began to develop in the late 1980s (Balta and Eke, 2011), whereas Mamak is a low income, working class town populated by migrants from mostly other central Anatolian cities. According to the Human Development Foundation in Turkey, based on the composite index of life expectancy, literacy rate and the standard of living, Çayyolu (Yenimahalle/Çankaya) is considered to be amongst the towns in Ankara with a very high standard of human development, whereas Mamak (Figure 2) is classified as being a district with medium human development (below the very high and high categories) (Şeker, Bakış, and Dizeci, 2018).

Before major mass housing projects started in the area, the land of the Çayyolu district was used for farming and the area was sparsely populated. Over time, a secular middle class socio-economic structure and antiAKP stance became two of the defining characteristics of Çayyolu. During the interviews taken for the study, a number of respondents referred to this defining nature of the Çayyolu community. For example one of the respondent's stated the following with a certain tone of elitism: "You know, Çayyolu is a very different place... It has a special demographic structure that is not found to be anywhere in Ankara... Melih Gökçek hates Çayyolu, he knows he will never get enough votes from here, and that's why he keeps messing with us."

On November 7, 2013, Turkish Parliament passed a new legislation that re-categorized the Çayyolu district so that it fell within the borders of Çankaya municipal- 

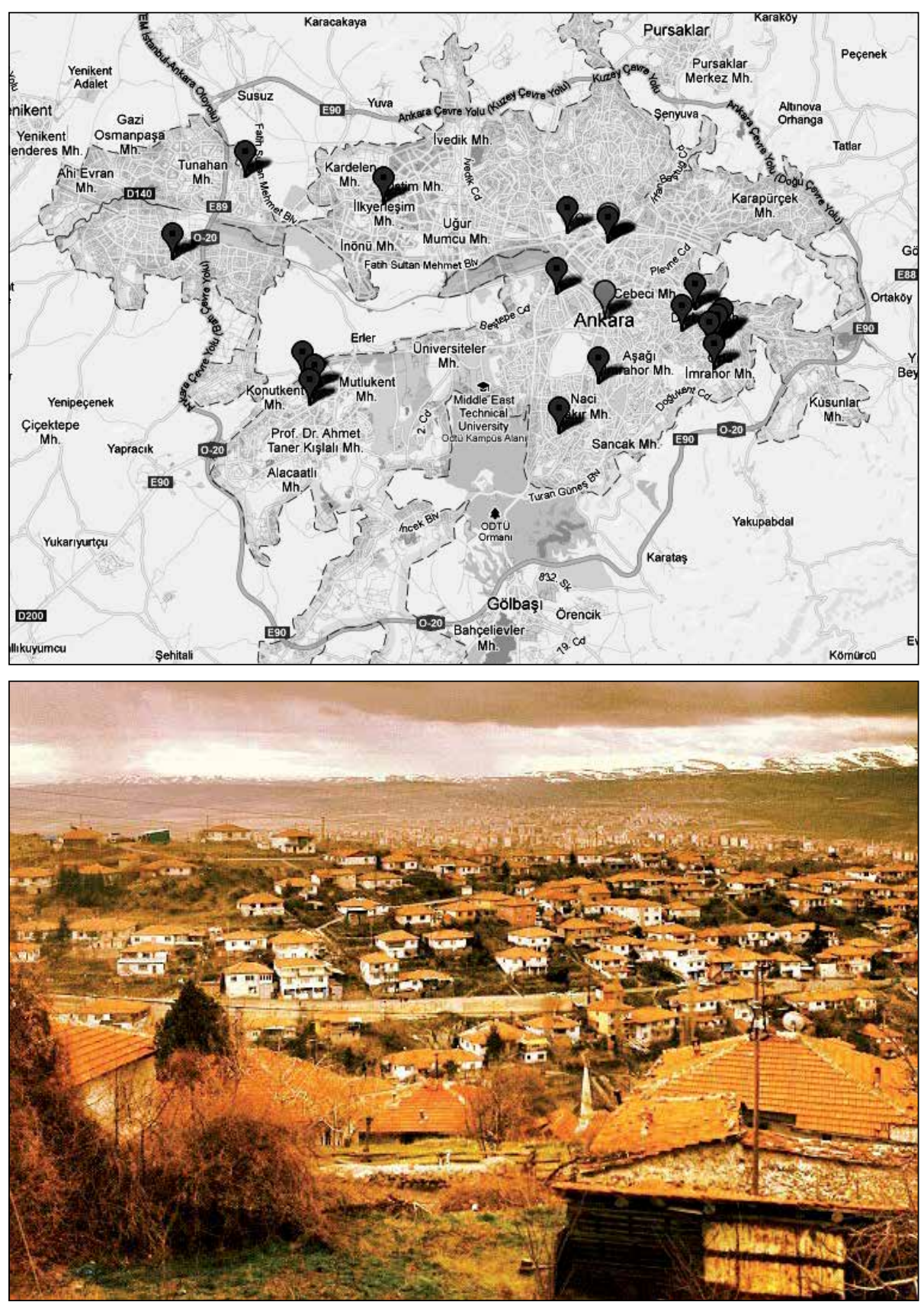

Figure 1. The spatial distribution of cases.
Figure 2. Picture from fieldwork in Mamak. Photograph by: Güneş Ertan ity, which is another district that consistently elects CHP mayors. For many CHP supporters, this act was an example of gerrymandering since one of the major reasons for CHP's victory in Yenimahalle, the previous district that Çayyolu had been a part of, was due to votes coming from Çayyolu.
Located on the North-East of Ankara, Mamak still has some gecekondu populated neighborhoods, despite increasing numbers of mass housing projects. Most inhabitants of Mamak are migrants from peripheral rural districts of Ankara, or from mid-Anatolian cities including Yozgat, Kırıkkale, Kırsehir, Çorum, Sivas, Kayseri, and 
Çankırı (Coşkun, 2003). Mamak is also known to have been a spatial center of the mobilization of left-wing groups in the 1960s and 1970s. Many left-wing groups carried out their organizing activities in the gecekondu neighborhoods of Mamak during these years, and these neighborhoods were known as being "liberated area" (kurtarılmış bölgeler) as it was difficult for police forces to physically gain access to certain neighborhoods (Coşkun 2003, p. 4).

Despite the apparent socio-economic and demographic differences between Çayyolu and Mamak, one striking similarity is the high number of neighborhood organizations in both areas. Although not all cases in this study involve mobilizations with formal organizations, large numbers of local civic organizations is still an indicator of a certain level of civic participation in both Mamak and Çayyolu, and may explain why these two locales have much a higher neighborhood rate of mobilizations in comparison to other districts and neighborhoods of Ankara.

The dominant type of organizations in Mamak and Çayyolu to some extent exhibit certain differences. Most organizations in Çayyolu can be categorized in three groups: (1) social clubs for leisurely activities such as arts and sports (e.g. The Çayyolu Music Society (Çayyolu Musiki Cemiyeti), The Çayyolu Folk Music Association (Çayyolu Halk Müziği Derneği), and The Bridge and Chess Club (Briç ve Satranç Sevenler Derneği); (2) Çayyolu branches of various service oriented organizations, mostly for the elderly and the disabled (e.g. The Çayyolu Association for Senior Citizens (Çayyolu Yaşlılara Saygı Derneği), The Association for Spinal Cord Injuries (Omurilik Felçlileri Derneği); and (3) Local branches of political organizations such as The Atatürkist Thought Association (Atatürkçü Düşünce Derneği) and The Modern Life Support Association (Çağdaş Yaşamı Destekleme Derneği).

Unlike Çayyolu, most neighborhood organizations in Mamak consist of village associations established by migrant communities. The two main functions of these organizations are to represent the interests of their members, and to provide formal and informal support for migrants in Ankara that lack the necessary social support networks. The formal function of these organizations is mostly to cover the wedding and funeral costs for needy families through membership dues (Coşkun, 2003). However, the organizations also act as enablers of social inclusion through informal functions such as find- ing a job, providing child support, and acting as intermediaries between local politicians and migrant communities (Coşkun, 2003). In addition, the People's Houses (Halkevleri) of the revolutionary leftist organization are also very active in Mamak, particularly in gecekondu neighborhoods. These organizations focus on organizing citizens against urban renewal projects in the area. In short, while the nature of associational life in Çayyolu and Mamak is very different, the positive relationship between organizational activity and political participation (Leighley, 1996) appears to be present at the neighborhood level of activism in both districts.

\section{Spontaneity and Protests}

A common characteristic that appears in all of the analyzed cases in the study is the "spontaneity" of the protests. According to Rosenthal and Schwartz (1989, p. 40): "Spontaneity in social movement refers to an impromptu action or series of actions undertaken by collectivity." Gemici, on the other hand, (2003) identifies two main characteristics of spontaneity during social protests: mobilization without any prior planning, and the rapid emergence of the protest group.

The fact that spontaneity is a factor in the cases is not surprising since most of these protests aim to halt the construction of cellular towers, and so therefore require immediate action. As most of the respondents mentioned in the interviews, it is much easier to stop the construction of a cellular tower than pressure authorities to demolish one. Participants are aware that if they can mobilize before a policy decision is made, and the implementation takes place, they are then more likely to succeed. This is because the reversal of existing policies and procedures require more complex legal processes and the participation of a larger and more diverse number of actors (Bosi and Uba, 2009).

\section{Not in my Backyard?}

The cases under study do not exactly qualify as being social movements for two main reasons. First, nearly all of the cases lack temporal continuity. As stated by McAdam and Snow (2010), the word "movement" suggests a social phenomenon that develops over time. However, the cases under study in this paper mostly consist of shortlived, neighborhood-level protests which emerge and are concluded within a matter of a few hours, or a few days at most. Secondly, most of these cases are not formally organized activities. According to McAdam and Snow (2010), there are very few social movements that are not 
associated with any kind of formal or informal SMOs. The reason for this is that professional organization is required in order to achieve a degree of continuity. While some of the cases analyzed have a local SMO involved in the organizing processes, many cases lack any formal organization and simply consist of interpersonal networks at the neighborhood level. Another characteristic of social movements is the presence of strong collective identities that provide a shared narrative and give the issue meaning (Diani, 2015). However, it is not possible for any of the cases analyzed in this study to be considered as having a movement level collective identity that could motivate individuals to participate beyond instrumental mechanisms.

The spontaneous and localized nature of the protest events raises the question of whether these events can be categorized as being Not in my Backyard events (NIMBYsim). NIMBYism driven mobilizations are characterized by the concerns of local residents about a proposed facility that may adversely affect their health, property values in their vicinity, and the quality of their daily life (Schively, 2007). Participants in NIMBYsim are usually considered as being motivated by selfish and "parochial" reasons (Esaiasson, 2014, p. 185). Protests against high-tech facilities, such as cellular towers, are common in Europe and North America due to concerns about electromagnetic waves (Graff and Broer, 2019). While public hearing types of meeting are common in European and North American cases, cases in Ankara lack any participatory mechanism for residents to be informed and for concerns to be raised as all cellular towers are secretly built by companies. This secrecy also greatly contributes to concerns of the citizens in Ankara. In fact, these cases would be better conceptualized as being "not in anyone's backyard" (NIABYism) because in many neighborhoods, (especially Çayyolu and Mamak) participants have either formal or informal ties with the Ankara branch of the Chambers of Electrical Engineers in Turkey (EMO), or with other organizations that regularly organize meetings and conferences to fight against electromagnetic pollution.

\section{Categorizing Mobilization Networks for Protest Events}

One way to understand the relationship between networks and the outcomes of mobilization is to analyze the varying performance of most commonly observed network structures, namely (1) Elite networks (2) Village networks (3) Hierarchical networks and (4) Isolated Cliques.
Elite Networks: Elite networks typically consist of a group of central actors with strong ties amongst each other, as well as a group of peripheral actors whose members have very few or no ties amongst each other (Siegel, 2009). Actors in the periphery are connected to the network through a limited number of ties with one or a few core actors. In elite networks, the strongly bonded core group has the capacity to mobilize and coordinate the activities of the overall network.

Village Networks: Village networks are generally highdensity subgroups, or cliques, in which almost everyone is connected to one another. These types of structures resemble villages and small towns with high levels of social control and strong ties among actors (Siegel, 2009). In village networks, there are very few actors that act as bridges between the groups. In other words, actors tend to have an equal number of connections and the network lacks strong central actors.

Hierarchical Networks: Hierarchical networks are the most centralized type of network structure. They closely resemble traditional bureaucratic structures and are characterized by comprising of an increasing number of actors as one moves from the top of the hierarchy to the bottom. Krackhardt (1994) describes such stylized hierarchical networks as each individual being connected to one actor above, while multiple actors are connected to that actor from below.

Isolated Clique Networks: The most obvious characteristic of this type of network is fragmentation of the network into multiple subgroups. According to Lamertz (2009), these types of networks suffer from an inability to coordinate across communities. Lamertz (2009) suggests that networks which have a topography that resembles that of Isolated Clique networks are extremely vulnerable to inter-group conflict and disagreements, and have limited potential for collective action.

\section{Hypotheses}

The structure of networks does not have a direct effect on the outcome. It is rather the case that the effects of networks occur in indirect ways through various mechanisms. The literature on mobilization success suggests that a desired policy change is likely to be achieved when the costs of repression, or the ignoring of demands, is greater than that of concessions (Biggs and Andrews, 2015; Rojas, 2006). Existing empirical work on outcomes highlight two distinct processes that seem, when combined with certain other conditions, to increase the 
costs of repression: (1) the utilization of disruptive tactics (Gamson, 1975/1990, Cress and Snow, 2000; Rojas 2006); and (2) the mobilization of large number of participants (Amenta, Caren, Chiarello, and Su, 2010; Siegel, 2009; Amenta, 2014).

Disruptive tactics require participants to be involved in high-risk activities that may well result in detention and the exposure to police violence. The evidence on whether disruptive strategies work or not is unclear due to diverse approaches for the measuring of collective action outcomes (Rojas, 2006; Giugni, 2004). Button's (1978) study on black riots in the US during the 1960s still provides us with the most nuanced description of the conditions under which disruptive tactics are more likely to succeed. According to Button (1978, p.134), disruptive protests are likely to succeed when:

1. It is possible for the demands of the protagonist to be met by those in power;

2. There is no threat of the disruption spreading and generating instability in the larger society (There is thus the implication that there is a limited number of participants);

3. The public and bystanders are sympathetic to the goals of the protestors;

4. Demands are clear, confined, tangible, and specific; and

5. Disruptive tactics are used in combination with peaceful measures.

The neighborhood protest events analyzed in this study very much meet Button's criteria. For example, let us consider local protests against cellular towers, the most common type of protest within the cases analyzed. If GSM companies and local authorities give up their efforts to build a cellular tower in one neighborhood, such protests do not appear to spread all over the country. Most people sympathize with the protestors, since many citizens of Turkey believe that cell sites are unsafe. The goals of the challengers are notably limited and clear: it is simply being asked that a cellular tower is removed. Finally, if the police take further action towards small crowds (including women and children in many cases) while claiming to ensure their safety, the public perception is likely to disapprove of this police intervention. Therefore, the first hypothesis is as follows: Hypothesis I: Disruptive tactics are more likely to succeed.

The second factor that is likely to be associated with successful outcomes is the participation of a large number of participants. Large crowds in a protest indicates: (1) high levels of public support for the cause, and thus the potential delegitimization of the antagonists, (2) larger threats and costs for the antagonists, (3) the greater likelihood of garnering more media attention, especially when the demands of the group may be relatively easily addressed by the antagonists, and (4) the cost of repression being higher in comparison to meeting the demands (Earl, Martin, and McCarthy, 2004 Luders, 2006; Button, 1978). However, when disruptive tactics are utilized by a large number of protestors, antagonists may be concerned about larger instabilities. I therefore hypothesize that disruptive tactics, and a large number of participants in protest events, are mutually exclusive causal conditions that are both likely to be associated with successful outcomes. The second main hypothesis of this analysis is therefore as follows: Hypothesis II: Protests with a large number of participants are more likely to succeed.

Network-Related Hypotheses: The nature of the mobilization networks in the protest events under study indirectly influences the outcomes by having an effect on the previously stated major hypotheses. As previously discussed, one crucial function of a network structure is the facilitating/hindering of coordination activities by affecting the flow of information. Consequently, if a network structure enables the rapid flow of information amongst a large number of people, more people are likely to participate in the protest events. The hypothesis reached is as follows: Hypothesis III: The network structure is associated with the size of protest events.

High levels of bonding social capital, or strong ties among the participants, are more likely to the cause of confrontation with the police and being taken into custody (Centola and Macy, 2007). Krackhardt (1992) defines strong ties as being those among people that have a long and frequent history of interaction with a level of affection among dyads. Networks in certain cases, such as friendships in immigrant communities, can be very strong. Such ties are present in village networks and, to a certain extent, in elite networks. Therefore, the last hypothesis is follows: Hypothesis IV: The presence of elite or village mobilization networks is associated with the utilization of disruptive tactics during protest events.

\section{Data}

The basis of the details of the 17 cases analyzed in this paper come from police records, with the list of protests events that took place in Ankara between 2007-2011 being provided by the archive of The Security General 
Directorate in Ankara. This data set also includes information about the approximate number of participants, the location of each event, and the main organization or social group that coordinated the event (if there was one). Studies on the reliability/validity of event analysis show that police records are the most reliable sources for information about past events (Koopmans and Rucht, 2002).

For each of the 17 cases, I carried out face-to-face semistructured interviews between October 2012 and March 2013. Some of these meetings occurred at the muhtar's office (elected head of neighborhood), while others were in coffee shops and places such as civic centers. My main goal in assessing these events was to identify the structure of the mobilization networks based on the qualitative descriptions provided by the respondents. In other words, I did not obtain sociometric data, but rather indirect measurement of the effects of mobilization networks, based on the eye-witness reports of informants. For example, in one case the goal was to initiate the reconstruction of an overpass in a working class neighborhood. A recently built four-lane road with fast-moving traffic passed through the neighborhood, threatening the safety of unsupervised children. From the statements obtained, such as the following, I derived that the mobilization structure resembled an elite core/periphery network with strong ties and high levels of motivation among the elites.

"The women in the neighborhood organized the protest event that stopped the traffic. They were very concerned for their children because there is no overpass and the traffic is very fast on the main road. While they were marching to block the road, they asked the people they saw at coffee shops and stores to join them."

In order to understand the different forms of mobilizations, the interview questions focused on the sources of information for the protests, as well as the nature of the relations among the participants.

Explaining Protest Outcomes: The main challenges of studying the outcomes of collective action include difficulties in confirming that the relationship between action and outcome is not spurious, identifying the exact causal mechanisms that link actions and outcomes, and operationalizing and measuring specific outcomes (Earl, 2004). This paper addresses the challenges associated with studying outcomes by focusing on mechanisms, using Qualitative Comparative Analysis (QCA), and by selecting reactive mobilizations that are based on the claims of the loss of political and/or economic resources (Tilly, 1978). The risk of spurious causation is minimized by applying a comparative approach to the study of multiple events/ networks, and also by considering all major causal factors associated with movement outcomes derived from predominant social movement theories, in addition to network related causal conditions. Finally, measurement and operationalization issues are addressed by selecting cases that have limited locus of change at the local level, and also those that aimed to reverse of policy decisions. Since the cases being studied do not aim at larger and complex social changes, but rather focus mostly on reversing minor, local policy decisions, it is relatively easy to label the outcomes of these cases as being either success or failure.

Additional Explanations: Additional explanations for collective action outcomes can be formulated based on major social movement theories, including political opportunity structure, cultural and framing, as well as resource mobilization-based theories.

Approaches related to political opportunity structures explain the outcomes of movements through shifts in the political environment and the influences of variations in the structure of power relations and institutional arrangements (Tilly, 1978; Kitschelt, 1986; Kriesi, 2004). According to McAdam (1996, p. 27), the main aspects of structures that aim to create political opportunities can be summarized as: "(1) The relative openness or closure of the institutionalized political system, (2) The presence or absence of elite allies, (3) The stability or instability of that wide set of elite alignments that typically undergird a polity, (4) The state's capacity and propensity for repression." The last two conditions identified by McAdam are not relevant for the cases under study because they are short-lived, even spontaneous in many instances, and so do not have a long life span that can be influenced by oscillations in the institutional environment. However, the cases do have different claim-makers, which lends a degree of variation in the absence or presence of elite allies across cases. In addition, the open vs. closed nature of the system also varies across cases due to the presence of different combinations of antagonists.

Cultural and framing approaches conceptualize mobilizations as being struggles over meanings and ideas produced by movement protagonists and antagonists. According to this perspective, movements can mobilize larger populations and garner public support when they are able to challenge the dominant definitions of reality, provide alternative meanings, and frame contested issues in a way that will resonate with a large number of people 
and their emotions (Benford and Snow, 2000; Polletta and Jasper, 2001). The framing perspective also informs the selection of causal conditions in terms of empirical analysis, especially with regard to the perception and framing of the issues by participants. Framing-related causal conditions mostly focus on the level of urgency and the significance of demands as perceived and framed by the participants.

The resource mobilization tradition in the study of social movements focuses on the role of organizational structure, material resources, and strategies utilized by activists for successful movement outcomes (McCarthy and Zald, 1977). A number of causal conditions are also derived from the resource mobilization theories in this study, such as the number of participants and movement tactics.

\section{Operationalization of Outcomes and Causal Conditions}

- Outcome (O): The Outcome condition indicates whether the protest event/s led to successful outcomes or not.

- History $(\mathrm{H})$ : This condition is coded based on the presence or absence of similar protest events in the neighborhood in the past.

- SMO (SMO): The SMO condition is coded as 1 if there is at least one SMO that participated in the protest.

- $\quad$ STOP (STOP): This causal condition shows whether the protest event is aiming to block an action (1), or trying to reverse a pre-existing condition (0).

- Perceived as Life Threatening (L): Based on framing theories, this condition evaluates whether protestors perceive the problem as being life-threatening, as in cellular tower and overpass cases. If the protagonists of the event perceive a life-threatening risk, they are assumed to be more motivated in pursuing the goals of the protest event.

- Elite (E): Based on theories of opportunity structures, this causal condition reflects whether the challengers have allies with elites. More specifically, this condition is coded based on the absence or presence of elected local politicians and/or members of the parliament at protest events.

- Population (P): The Population status is simply based on the number of estimated participants at the protest events, according to police records. This causal condition has multiple values: $0=$ a low number of participants, $1=$ a medium number of participants, and $2=$ a high number of participants. The assignment of cases for each category is based on Figure 4 . Cases with less than 70 participants are coded as 0 ; those between 70 and 500 are coded as 1 , and protests greater than 500 are re-coded as 2 .

- Spontaneity (SPO): The Spontaneity condition reflects whether the protest event emerged spontaneously or was pre-planned.

- Disruptive (D): This condition shows the absence or presence of disruptive tactics, such as physical confrontation with the police.

- Network (NS): This multi-value condition signifies four main types of mobilization networks: isolated cliques (0), village (1), elite (2), and hierarchy (3).

Analysis using Qualitative Comparative Analysis

Qualitative Comparative Analysis (QCA) is used for medium- $n$ cases in order to identify different causal mechanisms that may lead to the same outcome. QCA is based on the assumption that causal relations are complex, and that different combinations of causal conditions may lead to the same outcome (Ragin, 2008). As asserted by Amenta et al. (2010), QCA is one of the few techniques that enable researchers to elucidate different causal and combinational mechanisms that are associated with movement outcomes. Ragin and Sedziaka (2013, p.1031) also argue that QCA is a particularly suitable method for mobilizations because "social movements are conjectural in nature, and a central goal of research on social movements and collective action is to unravel the relevant causal recipes and to specify their various ingredients." By using QCA, this study therefore attempts to reveal multiple mechanisms that are at work in facilitating successful collective action outcomes.

QCA utilizes set theoretic approaches to compare cases included in the analysis. Each case studied here is represented as a combination of causal and outcome conditions. These combinations are subsequently compared with each other and logically simplified to produce causal recipes for positive outcomes.

The main concern of the study is to attempt to understand the relation between network structures and collective action outcomes. Since the condition of network structures consist of multiple categories, Multi-Value QCA (mvQCA) is used as the data analysis technique. mvQCA can be considered as being an extension of crisp QCA (Cronqvist and Berg-Schlosser 2009). The main difference between mvQCA and traditional crisp QCA 
is that the former allows the incorporation of nominal- and ordinal-level measures as causal conditions, in addition to dichotomous ones (Cronqvist, 2003). Consequently, mvQCA avoids the loss of information and decreases the chances of observing contradictory configurations (Cronqvist and Berg-Schlosser, 2009).

\section{Findings and Discussion}

All analysis is carried out in $R$ environment using package QCA (Dusa and Thiem, 2016). Data Table I provides details of the conditions and cases before the data is transformed into a truth table. Analysis is then performed to reveal causal paths that are associated with successful protest outcomes.

Truth Table II summarizes the cases. Each row of the truth table shows an empirically observed combination of causal conditions and outcomes for Model I. According to the truth table, there are 12 configurations, and nine cases with successful outcomes, with six configurations covering these nine cases.

Logical remainders, i.e., logically possible configurations that are not observed empirically (Rihoux and Lobe, 2009), are not displayed in the truth table. There are no contradictions in the truth table, meaning that there are no similar configurations which lead to different outcomes. The most common configuration is the fifth configuration, which applies to cases \#14, $\# 15$, \#16, and \#17.

Necessity analysis did not reveal any necessary conditions. A causal condition is necessary when the outcome constitutes a subset of that condition (Ragin, 2008). The following step was for intermediate solutions to be used for identifying causal configurations, paths that are associated with successful outcomes. Directional expectations (hypotheses) for this model are as follows: based on a political opportunity structure approach, elite support and protests to stop a policy or a project,

\begin{tabular}{|c|c|c|c|c|c|c|c|c|c|c|c|c|c|c|c|c|c|}
\hline 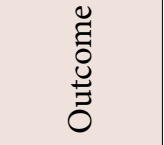 & 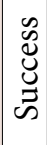 & $\begin{array}{l}0 \\
\tilde{u} \\
\breve{u} \\
\tilde{s} \\
\omega\end{array}$ & 芯 & 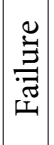 & 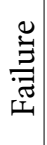 & 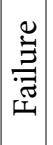 & 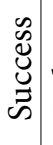 & 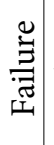 & 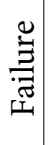 & $\begin{array}{l}\infty \\
0 \\
\tilde{u} \\
\vdots \\
\tilde{s}\end{array}$ & 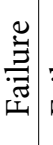 & 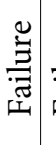 & 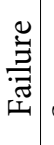 & 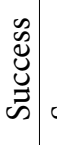 & 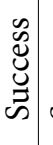 & 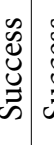 & 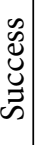 \\
\hline 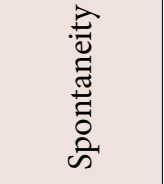 & 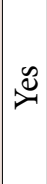 & $\stackrel{0}{z}$ & $\approx$ & $\approx$ & $\stackrel{\circ}{z}$ & $\stackrel{0}{z}$ & ż & ż & $\stackrel{0}{z}$ & Z̊. & Zे. & Z̊. & $\stackrel{\mathscr{Z}}{\mathscr{2}}$ & ż & $\stackrel{\mathscr{Z}}{\approx}$ & 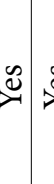 & $\stackrel{\mathscr{e}}{*}$ \\
\hline 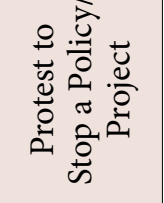 & $\stackrel{\circ}{Z}$ & $\stackrel{\circ}{Z}$ & $\stackrel{0}{z}$ & $\stackrel{\circ}{Z}$ & $\stackrel{\circ}{z}$ & $\stackrel{0}{z}$ & 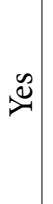 & ż & ż & Z̊, & ż, & $\stackrel{\circ}{z}$ & $\cong$ & $\stackrel{\infty}{\infty}$ & $\stackrel{\mathbb{Z}}{\approx}$ & 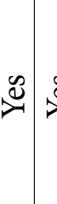 & $\stackrel{\mathscr{Z}}{\approx}$ \\
\hline 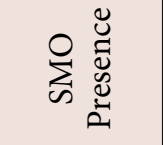 & 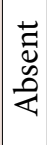 & 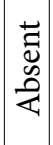 & 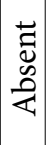 & 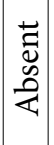 & 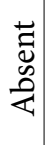 & 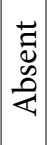 & 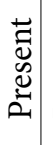 & 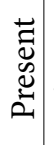 & $\begin{array}{l}\overrightarrow{\vec{v}} \\
0 \\
0 \\
\vec{\psi}\end{array}$ & 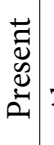 & 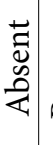 & 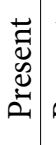 & 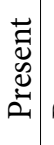 & 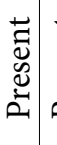 & 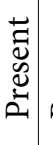 & 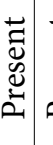 & 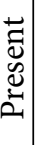 \\
\hline 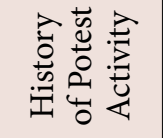 & ż & $\stackrel{\circ}{z}$ & $\stackrel{0}{z}$ & $\stackrel{0}{z}$ & $\stackrel{\circ}{z}$ & $\stackrel{0}{z}$ & $\approx$ & $\stackrel{\infty}{\approx}$ & $\dot{z}$ & $\stackrel{\infty}{\approx}$ & ż. & $\stackrel{\infty}{\approx}$ & $\cong$ & $\approx$ & $\stackrel{\infty}{\approx}$ & $\approx$ & 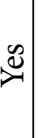 \\
\hline 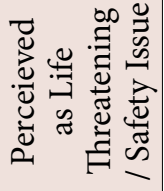 & $\triangleq$ & $\stackrel{0}{z}$ & $\underset{\sim}{\infty}$ & 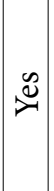 & 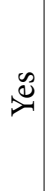 & $\stackrel{\infty}{*}$ & ฉ̊ & Zे & ż & $\stackrel{\infty}{\approx}$ & $\stackrel{\infty}{\approx}$ & $\triangleq$ & $\triangleq$ & $\stackrel{\infty}{\approx}$ & $\stackrel{\infty}{\approx}$ & 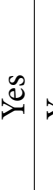 & $\stackrel{\mathscr{\Xi}}{\approx}$ \\
\hline 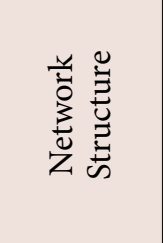 & 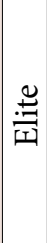 & 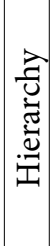 & 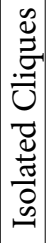 & 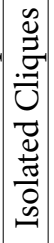 & 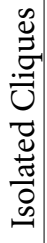 & 产 & 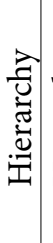 & 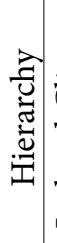 & 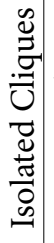 & . & 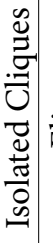 & . & 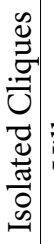 & 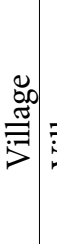 & $\begin{array}{l}\stackrel{\infty}{\infty} \\
\stackrel{\Xi}{5}\end{array}$ & 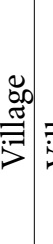 & 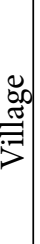 \\
\hline 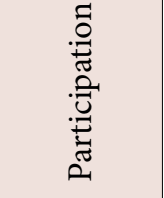 & $\stackrel{P}{R}$ & ৪ & 10 & $\stackrel{\sim}{~}$ & ষి & $\begin{array}{l}10 \\
12\end{array}$ & $\begin{array}{l}8 \\
8 \\
10 \\
1\end{array}$ & $\begin{array}{l}8 \\
\text { in }\end{array}$ & $\begin{array}{c}\text { in } \\
\text { ñ }\end{array}$ & $\begin{array}{l}8 \\
\text { in }\end{array}$ & 요 & $\begin{array}{l}8 \\
\text { in }\end{array}$ & 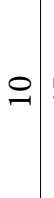 & \&) & 尺. & 의 & 10 \\
\hline 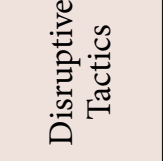 & $\stackrel{\infty}{\infty}$ & ż & $\stackrel{0}{z}$ & $\stackrel{\circ}{z}$ & $\stackrel{\circ}{Z}$ & $\stackrel{0}{z}$ & $\stackrel{\circ}{z}$ & z) & ż & ¿̊, & ¿̊. & $\overbrace{}^{\infty}$ & ¿̊. & $\stackrel{\infty}{\infty}$ & $\stackrel{\infty}{\approx}$ & 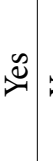 & $\approx$ \\
\hline 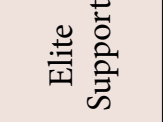 & 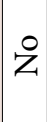 & $\stackrel{0}{z}$ & $\approx$ & $\stackrel{0}{Z}$ & $\stackrel{0}{z}$ & $\stackrel{\circ}{Z}$ & $\stackrel{\infty}{\approx}$ & $\stackrel{\infty}{\approx}$ & 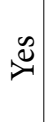 & $\stackrel{\infty}{\infty}$ & Z̊, & ¿̊, & ¿̊. & $\stackrel{\circ}{z}$ & ¿̊, & $\stackrel{\circ}{z}$ & $\stackrel{\circ}{Z}$ \\
\hline$\tilde{J} 气$ & - & $N$ & $m$ & + & 10 & 0 & $\wedge$ & $\infty$ & $a$ & 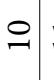 & $\exists$ & $\simeq$ & $\stackrel{m}{=}$ & $\Xi$ & $\stackrel{\Omega}{=}$, & $\underset{-1}{0}$ & $\triangle$ \\
\hline
\end{tabular}


Table II. Truth Table for Model I Outcome Success

\begin{tabular}{|c|c|c|c|c|c|c|c|c|}
\hline Case IDs & $\begin{array}{c}\text { Elite } \\
\text { Support } \\
\text { (E) }\end{array}$ & $\begin{array}{c}\text { Disruptive } \\
\text { Tactics } \\
\text { (D) }\end{array}$ & $\begin{array}{c}\text { Participation } \\
(\mathrm{P})\end{array}$ & $\begin{array}{c}\text { Perceieved } \\
\text { as Life } \\
\text { Threatening } \\
\text { / Safety } \\
\text { Issue (L) }\end{array}$ & $\begin{array}{c}\text { SMO } \\
\text { Presence } \\
\text { (SMO) }\end{array}$ & $\begin{array}{c}\text { Protest to } \\
\text { Stop a Policy/ } \\
\text { Project } \\
\text { (STOP) }\end{array}$ & $\mathrm{n}$ & Outcome \\
\hline $4,6,11$ & 0 & 0 & 0 & 1 & 0 & 0 & 3 & 0 \\
\hline 13 & 0 & 0 & 0 & 1 & 0 & 1 & 1 & 0 \\
\hline 5 & 0 & 0 & 1 & 1 & 0 & 0 & 1 & 0 \\
\hline 2 & 0 & 0 & 2 & 0 & 0 & 0 & 1 & 1 \\
\hline $14,15,16,17$ & 0 & 1 & 0 & 1 & 0 & 1 & 4 & 1 \\
\hline 1 & 0 & 1 & 1 & 1 & 0 & 0 & 1 & 1 \\
\hline 12 & 0 & 1 & 1 & 1 & 1 & 0 & 1 & 0 \\
\hline 3 & 1 & 0 & 0 & 1 & 0 & 0 & 1 & 1 \\
\hline 9 & 1 & 0 & 1 & 0 & 0 & 0 & 1 & 0 \\
\hline 8 & 1 & 0 & 1 & 0 & 1 & 0 & 1 & 0 \\
\hline 7 & 1 & 0 & 2 & 0 & 1 & 1 & 1 & 1 \\
\hline 10 & 1 & 0 & 2 & 1 & 1 & 0 & 1 & 1 \\
\hline
\end{tabular}

Table III. Minimization Results for Model I Outcome Success

\begin{tabular}{|c|c|c|c|c|c|}
\hline $\begin{array}{c}\text { Name of } \\
\text { Configuration }\end{array}$ & Configurations & Unique Coverage & Raw Coverage & Inclusion & Cases \\
\hline Large Crowds & $\mathrm{P}\{2\}$ & 0.222 & 0.333 & 1 & $2,7,10$ \\
\hline $\begin{array}{c}\text { Clientelism at } \\
\text { Work }\end{array}$ & $\mathrm{E}\{1\}^{\star} \mathrm{L}\{1\}$ & 0.111 & 0.222 & 1 & 3,10 \\
\hline Angry Locals & $\mathrm{D}\{1\}^{\star} \mathrm{L}\{1\}^{\star} \mathrm{SMO}\{0\}$ & 0.556 & 0.556 & 1 & $14,15,16,17,1$ \\
\hline
\end{tabular}

before implementation takes place, are expected to positively contribute to the outcome of a protest. Similarly, based on framing approaches, if the participants and the larger public perceive the issue as being a serious health/ safety risk, successful outcomes are expected to be more likely.

The intermediate solution for the first model led to three configurations, as displayed in Table III. In accordance with Hypothesis II, the first configuration, labeled as Large Crowds, solely consists of the presence of a high number of participants. The second configuration, Clientelism at Work, on the other hand, combines the presence of elite allies with the presence of perception of life/ health risks in relation to the issue being contested. This finding is also consistent with the literature, and demon- strates that elites of the protagonists may tend to apply more pressure on decision makers if the issue is framed as being urgent and life-threatening. The final configuration, Angry Locals, also largely confirms Hypothesis I by combining the presence of disruptive tactics, perception of the issue as being life-threatening, and the absence of formal SMOs. As previously discussed, this path is not surprising as disruptive tactics are more likely to be successful if there is strong sympathy and support from the general public. A lack of formal organizations, and framing of the issue as a matter of health, are both conditions that generally increase public sympathy for the protagonists, especially in Turkey. The reason for this is the presence in Turkey of a general distrust towards SMOs, particularly politically-oriented ones. Even the Turkish word that denotes that a person is a member of an SMO, 


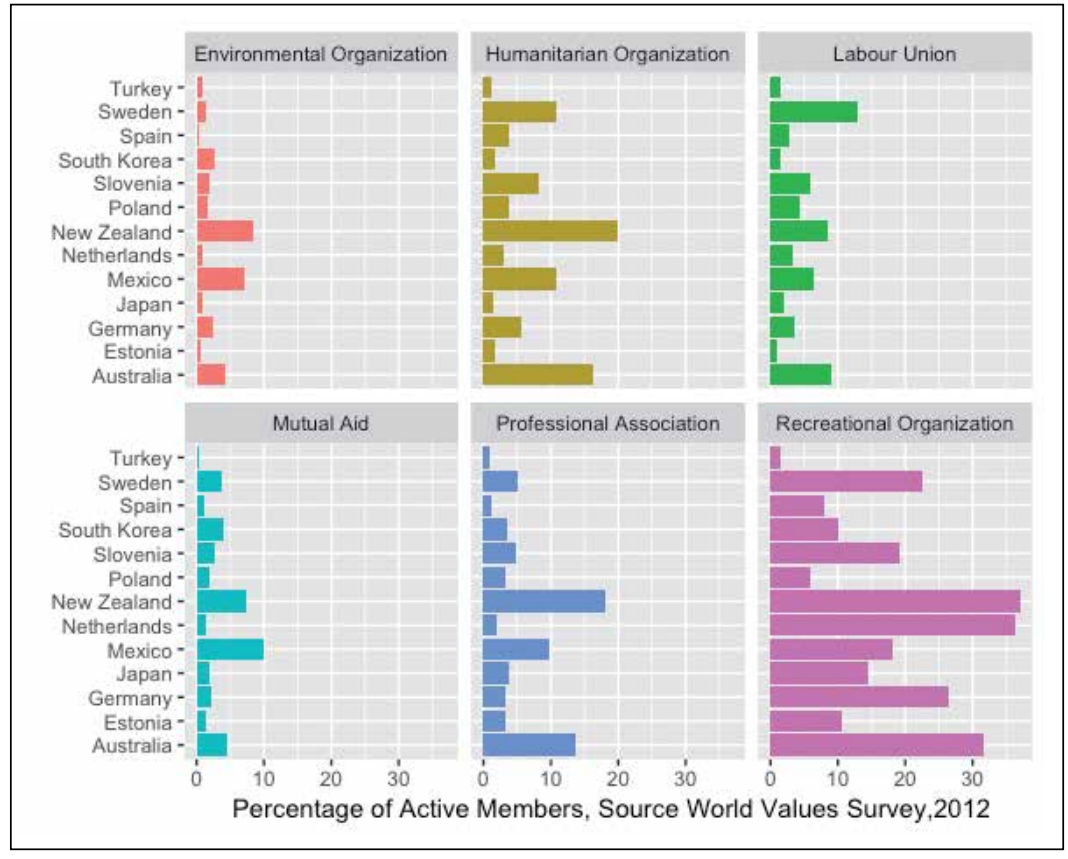

Figure 3. Participation in civil society in Turkey vs. OECD countries. Source: World Values Survey, 2012. örgütlü, is used in a pejorative way by both policy makers and the majority of the public. This trend in civil society in Turkey is reflected in low membership rates in civil society organizations, as presented in Figure 3. A lack of trust towards civil society organizations in the country is revealed in numerous survey studies (e.g. Çarkoglu and Aytaç, 2016).

An example of this trend can be seen in the fact that many protestors during the 2013 Gezi uprising did not belong to any political organization, and this was perceived to be a positive trait of the movement by many, which in turn made the protagonists' claims more legitimate (Konda, 2013).

Analysis of the remaining section investigates whether the second phase of the causal model is also plausible. Causal conditions that may be associated with the Elites at Work configuration are not examined any further, because having elite allies is most likely to be explained by other factors in the neighborhood such as class, religion, or ethnicity. The following truth table displays all the empirically observed configurations when the outcome is a high number of participants.

This analysis produces a total of 12 configurations, only five of which had a high number of participants in the protest events, while the remaining nine had negative outcomes. The truth Table IV shows that Cases \#7 and \#8,
Cases \#5 and \#11, Cases \#3 and \#4, and Cases \#15, \#16, and \#17 have the same configurations of 0 s and 1s. The rest of the cases have unique configurations. The absence of spontaneity is identified as being the only necessary condition. This is an intuitive finding as mobilizing large crowds is clearly more likely if the event is pre-planned.

In order to obtain the intermediate solutions, a previous history of mobilization in the neighborhood, the presence of SMOs, and the absence of spontaneity are included in directional expectations. Minimal formulas reveal two different causal paths to mobilizing a high number of participants for a protest event. The first path, entitled Hierarchical Networks, combines planning activity with presence of a hierarchical network structure to disseminate information about the protest events Table V. As previously discussed, hierarchical social networks are criticized for not being robust enough, and also for lacking the structural properties for feedback loops. However, this finding suggests that these types of networks may be valuable if the main purpose is to simply disseminate information for a future event when the possible participants are highly motivated.

The hierarchical mobilization structures in the cases analyzed are the result of the existence of a vast number of mass high-rise housing projects in the suburbs of Ankara. Each housing project has a manager elected by the oc- 
Table IV. Truth Table Model II Outcome Participation

\begin{tabular}{|c|c|c|c|c|c|c|c|}
\hline Case IDs & $\begin{array}{c}\text { Perceieved as Life } \\
\text { Threatening / Safety } \\
\text { Issue (L) }\end{array}$ & $\begin{array}{c}\text { History } \\
\text { of Potest } \\
\text { Activity (H) }\end{array}$ & $\begin{array}{c}\text { SMO } \\
\text { Presence } \\
\text { (SMO) }\end{array}$ & $\begin{array}{c}\text { Network } \\
\text { Structure } \\
\text { (NS) }\end{array}$ & $\begin{array}{c}\text { Spontaneity } \\
\text { (SPO) }\end{array}$ & $\mathrm{n}$ & Outcome \\
\hline 9 & 0 & 0 & 0 & 0 & 0 & 1 & 0 \\
\hline 2 & 0 & 0 & 0 & 3 & 0 & 1 & 1 \\
\hline 7,8 & 0 & 1 & 1 & 3 & 0 & 2 & 1 \\
\hline 5,11 & 1 & 0 & 0 & 0 & 1 & 2 & 0 \\
\hline 3,4 & 1 & 0 & 0 & 0 & 0 & 2 & 0 \\
\hline 6 & 1 & 0 & 0 & 2 & 0 & 1 & 0 \\
\hline 1 & 1 & 0 & 0 & 2 & 1 & 1 & 0 \\
\hline 13 & 1 & 1 & 0 & 0 & 1 & 1 & 0 \\
\hline 14 & 1 & 1 & 0 & 1 & 1 & 3 & 0 \\
\hline $15,16,17$ & 1 & 1 & 1 & 2 & 0 & 1 & 1 \\
\hline 12 & 1 & 1 & 1 & 3 & 0 & 1 & 1 \\
\hline 10 & 1 & & & & & & 0 \\
\hline
\end{tabular}

Table V. Minimization Results Model II Outcome Participation

\begin{tabular}{|l|c|c|c|c|c|}
\hline Name of Configuration & Configurations & $\begin{array}{c}\text { Unique } \\
\text { Coverage }\end{array}$ & $\begin{array}{c}\text { Raw } \\
\text { Coverage }\end{array}$ & Inclusion & Cases \\
\hline Hierrarchical Networks & $\mathrm{NW}\{3\}^{\star} \mathrm{SPO}\{0\}$ & 0.667 & 0.667 & 1 & $2,8,7,10$ \\
\hline Organized Elites & $\mathrm{H}\{1\}^{\star} \mathrm{SMO}\{1\}^{*} \mathrm{SPO}\{0\}^{*} \mathrm{NS}\{2\}$ & 0.167 & 0.167 & 1 & $8,7,12,10$ \\
\hline
\end{tabular}

cupants, and the managers of housing projects collectively mobilize residents from top to bottom, even though mobilizations may be initiated as a result of complaints from residents. The highest level of the hierarchy involves decision-making by the informal organizations of managers of the apartment complexes. At the next level, each manager contacts the manager of each other apartment building (up to 30 buildings may be involved in this process). Next, each apartment building manager communicates the upcoming protest event to the residents of his/ her apartment building (up to 70 apartment units).

This finding suggests that the long-criticized suburban housing-complex projects that squeeze large numbers of people into high-rise apartment buildings may actually create some unintended opportunities for effective organization. This occurs through the enabling of the formation of hierarchical information dissemination networks across large populations that are not readily available in the more traditional, urban apartments that are dominant in Turkey (i.e. smaller apartment buildings with very limited formal/informal ties to neighboring buildings). This finding is supported by the evidence on the role of spatial environments in facilitating and/or hindering collective action (Sewell, 2001; Zhao 1998). By determining co-presence, spatial arrangements may have a crucial impact on the formation and nature of social networks that are shown to be the basis of mobilization in numerous collective action events (e.g. Zhao, 1998; Futrell, and Simi, 2004). As Zhao (1998, p.195) states, space matters in understanding the mobilization processes during collective action because ".. it determines the structure and strength of social networks as well as the spatial position and routine activities of people in a community."

The second path, Organized Elites Network, combines the absence of spontaneous protest with the presence of a history of previous mobilization in the neighborhood 
and organizational efforts by SMOs (Table V). This finding indicates that if individuals have previous experience of participation in protest events, they are more likely to participate again. Moreover, when organizing efforts are facilitated by the resources of a formal SMO in combination with a lack of time pressure, more people are likely to attend protest events.

The findings of the last part of the causal model are presented in Tables VI and VII. This final analysis examines the relationship between network structures and the tendency for disruptive tactics.

The final truth table displays 13 configurations in which outcome is either the absence or the presence of disruptive tactics. Among those, only five configurations have positive outcomes for the presence of disruptive events. The truth table used in the minimization process shows that Cases \#5 and \#11, Cases \#3 and \#4, and Cases \#15,
\#16, and \#17 all have the same configurations of 0 s and $1 \mathrm{~s}$. The rest of the cases have unique configurations. Necessity analysis indicates that the perception of a lifethreatening problem by the protagonists is a necessary condition for the presence of disruptive, high-risk tactics within the case of neighborhood-level protest events. This comes as a natural finding, since physically confronting police forces is a highly risky course of action. This is especially in Turkey, as became apparent in the violent police reaction to the peaceful Gezi protests, and it is expected that groups who feel they are campaigning for a life-threatening issue may be more likely to take such risks. This finding is also in parallel with the literature stemming from the previously mentioned Button (1978), as well as with Keck and Sikkink (1999, p. 99) who claim issues pertaining to "physical harm to innocent individuals" tend to resonate more easily with public opinion and may thus render a mobilization more legitimate.

Table VI. Truth Table for Model III Outcome Disruptive

\begin{tabular}{|c|c|c|c|c|c|c|c|}
\hline Case IDs & $\begin{array}{c}\text { Perceieved as Life } \\
\text { Threatening / } \\
\text { Safety Issue (L) }\end{array}$ & $\begin{array}{c}\text { History } \\
\text { of Potest } \\
\text { Activity (H) }\end{array}$ & $\begin{array}{c}\text { Network } \\
\text { Structure } \\
\text { (NS) }\end{array}$ & $\begin{array}{c}\text { Protest to Stop } \\
\text { a Policy/Project } \\
\text { (STOP) }\end{array}$ & $\begin{array}{c}\text { Spontaneity } \\
\text { (SPO) }\end{array}$ & $\mathrm{n}$ & Outcome \\
\hline 9 & 0 & 0 & 0 & 0 & 0 & 1 & 0 \\
\hline 2 & 0 & 0 & 3 & 0 & 0 & 1 & 0 \\
\hline 8 & 0 & 1 & 3 & 0 & 0 & 1 & 0 \\
\hline 7 & 0 & 1 & 3 & 1 & 0 & 1 & 0 \\
\hline 5,11 & 1 & 0 & 0 & 0 & 0 & 2 & 0 \\
\hline 3,4 & 1 & 0 & 0 & 0 & 1 & 2 & 0 \\
\hline 6 & 1 & 0 & 2 & 0 & 0 & 1 & 0 \\
\hline 1 & 1 & 0 & 2 & 0 & 1 & 1 & 1 \\
\hline 13 & 1 & 1 & 0 & 1 & 1 & 1 & 0 \\
\hline 14 & 1 & 1 & 1 & 1 & 0 & 1 & 1 \\
\hline $15,16,17$ & 1 & 1 & 1 & 1 & 1 & 3 & 1 \\
\hline 12 & 1 & 1 & 2 & 0 & 0 & 1 & 1 \\
\hline 10 & 1 & 1 & 3 & 0 & 0 & 1 & 0 \\
\hline
\end{tabular}

Table VII. Minimization Results for Model III Outcome Disruptive

\begin{tabular}{|l|c|c|c|c|c|}
\hline $\begin{array}{l}\text { Name of } \\
\text { Configuration }\end{array}$ & Configurations & $\begin{array}{c}\text { Unique } \\
\text { Coverage }\end{array}$ & $\begin{array}{c}\text { Raw } \\
\text { Coverage }\end{array}$ & Inclusion & Cases \\
\hline Spontanues Elites & $\mathrm{L}\{1\}^{*} \mathrm{NS}\{2\}^{*} \mathrm{SPO}\{1\}$ & 0.167 & 0.167 & 1 & 1 \\
\hline Activist Elites & $\mathrm{L}\{1\}^{*} \mathrm{NS}\{2\}^{*} \mathrm{H}\{1\}$ & 0.167 & 0.167 & 1 & 12 \\
\hline Villagers & $\mathrm{L}\{1\}^{*} \mathrm{NS}\{1\}^{\star} \mathrm{H}\{1\}^{*} \mathrm{STOP}\{1\}$ & 0.667 & 0.667 & 1 & $14,15,16,17$ \\
\hline
\end{tabular}


As with previous analyses, the intermediate solution is used in the final minimization. Perception of the issue as being life threatening, the presence of a previous history of protest activity, strong ties, most commonly, in village-type networks, and the protest aiming to stop a policy or project, are all expected to be factors which have a positive association with the prevalence of disruptive tactics.

Minimization results have revealed three paths, all of which contain a degree of strong ties-based network structures. These are either in the form of village networks or elite networks which combine strong ties among core actors, and weaker ties with the peripheral nodes.

The first two paths demonstrate very similar processes: the issue is perceived to be a health or safety issue, and there is the presence of some strong ties which may lead to disruptive tactics, either in combination with a spontaneous mobilization or in a neighborhood with a history of previous activism. The juxtaposition of spontaneity and disruptive tactics in the Spontaneous Elites configuration suggests a mechanism that triggers "pre-existing sentiments and experiences" (Snow and Moss, 2014, p. 12). This is an interesting finding and indicates that, when spontaneity is combined with higher risks, only strong ties can mobilize people. Overall, this path suggests that trust and shared identity is an important factor in mobilizing people for risky action, especially when there are time constraints.

In the Activist Elites recipe, however, strong ties are tapped for high-risk events if potential participants have previous experience of protest participation. Previous research also confirms that participation in social movement activity is more likely for individuals that have a history of participation (Diani and McAdam, 2003).

Finally, the Villagers path specifies that strong ties present in village networks can easily be activated for disruptive tactics when participants have a history of activism and are mobilized to block a project that they deem hazardous to their health.

What are the antecedents of these strong ties? On site interviews reveal that strong ties may stem from a variety of sources, and that the ones among the cases in the study includes regular attendance at a mosque, migrants' and women's solidarity networks, and networks of elderly small shop-owners. However, QCA analysis has shown that these relations can be more easily activated for highrisk disruptive mobilizations if, and only if, the issue is perceived by participants and the larger public to pose a health or safety risk.

\section{Conclusion}

This paper aims to understand the role of pre-existing interpersonal networks in shaping neighborhood-level protest outcomes in Ankara between 2007-2011. Based on a two-level QCA analysis, findings have identified that disruptive tactics and widespread participation are the two key causal conditions that tend to be shaped by the structure and/or the nature of pre-existing interpersonal networks in the neighborhoods.

Among the analyzed cases, the presence of strong ties amongst a small number of residents is shown to be a pre-condition for the emergence of disruptive tactics. Strong ties, such as long-term friendship among migrant women in squatter neighborhoods, were instrumental for the presence of high levels of commitment. This is reflected in the willingness to participate in high-risk protest events involving disruptive techniques. However, these networks are only activated when the issue is perceived to be a health or safety risk.

In order to facilitate the mobilization of a large number of protestors at the neighborhood level, hierarchical information networks tend to be crucial if potential participants have low thresholds for participation and high levels of motivation and commitment, as is the case in most cellular tower-related cases. The spatial plans and the nature of apartment complexes has been identified as being the main source of these hierarchical networks.

Overall, the study shows that spatiality interacts with the formation of social networks. Whether the setting of the protest event is in a high rise apartment complex or in a gecekondu neighborhood may have an affect on the emergence of mobilization structures. Moreover, there can be a number of antecedents of neighborhood mobilization networks in contexts similar to Ankara, such as within informal ties that exist in places of worship and in coffee houses, or within strong solidarity networks among immigrants. There is the potential for further investigations into how spatiality interacts with different types of preexisting informal ties in future studies. 


\section{References}

Amenta, E. (2014). How to analyze the influence of movements. Contemporary Sociology 43(1), 16-29.

Amenta, E., Caren, N., Chiarello, E., and Su, Y. (2010). The political consequences of social movements. Annual Review of Sociology 36, 287-307.

Balta, M. O., and Eke, F. (2011). Spatial reflection of urban planning in metropolitan areas and urban rent; a case study of Çayyolu, Ankara. European Planning Studies, 19(10), 1817-1838.

Batuman, B. (2013). City profile: Ankara. Cities, 31, 578-590.

Bayraktar, S. U. (2007). Turkish municipalities: reconsidering local democracy beyond administrative autonomy. European Journal of Turkish Studies. Retrieved from https:// journals.openedition.org/ejts/1103

Bayraktar, U. (2018). Policy-making at local level: an analysis of Turkish municipalities. In C. Bakir and G. Ertan (Eds.) Policy analysis in Turkey (pp. 105-120). Bristol: University of Bristol.

Benford, R. D., and Snow, D. (2000). Framing processes and social movements: an overview and assessment. Annual Review of Sociology, 26, 611-639.

Biggs, M., and Andrews, K. T. (2015). Protest campaigns and movement success desegregating the US south in the early 1960s. American SociologicalReview [Published onlinebefore print March 9, 2015). doi:10.1177/0003122415574328ç

Borgatti, S. P., Mehra,A., Brass, D. and Labianca, G. (2009). Network analysis in the social sciences. Science, 323(5916), 892-895.

Bosi, L., and Uba, K. (2009). Introduction: the outcomes of social movements. Mobilization: An International Quarterly, 14(4), 409-415.

Button, J. W. (1978). Black violence: political impact of the $1960 \mathrm{~s}$ riots. Princeton, NJ: Princeton University Press.

Çarkoğlu, A., and Aytaç, E. (2016). Türkiye'de bireysel bağışçllık ve hayırseverlik. İstanbul: TÜSEV.

Centola, D., and Macy, M. (2007). Complex contagions and the weakness of long ties. American Journal of Sociology, 113(3), 702-734.

Coşkun, M. (2003). Village associations as migrants' formal organizations: an empirical study in Mamak Ankara. Unpublished Doctoral Dissertation, Bilkent University, Ankara.

Cress, D., M., and Snow, D. A. (2000). The outcomes of homeless mobilization: the influence of organization, disruption, political mediation, and framing. American Journal of Sociology, 105 (4), 1063-1104.
Cronqvist, L. (2003). Using multi value logic synthesis in social science. Paper presented at $2^{\text {nd }}$ General Conference of the European Consortium for Political Research (ECPR), Marburg.

Cronqvist, L., and Berg-Schlosser D. (2009). Multi-value QCA (mvQCA). In B. Rihoux, and C. C. Ragin.(Eds.). Configurational comparative methods: qualitative comparative analysis (QCA) and related techniques (pp. 6987). Thousand Oaks, CA: SAGE.

Diani, M. (2015). The cement of civil society. New York: Cambridge University.

Diani, M., (2003). Introduction: social movements, contentious actions, and social networks: from metaphor to substance? In M. Diani and D. McAdam (Eds.). Social movements and networks: relational approaches to collective action (pp.118). Oxford: Oxford University.

Diani, M., and McAdam, D., (2003). Social movements and networks: relational approaches to collective action. Oxford: Oxford University.

Doğan, A. E. (2005). Gökçek'in Ankara'yı neo-liberal rövanşçılıkla yeniden kuruşu. Planlama Dergisi, 4, 130-138.

Duşa, A., and Thiem, A. (2016). Package QCA. Retrieved from https://cran.r-project.org/web/packages/QCA/QCA.pdf.

Earl, J. (2004). The cultural consequences of social movements. In D. A. Snow, S. A. Soule, and H. Kriesi (Eds.). The Blackwell companion to social movements. (pp. 508-530). Malden, MA: Blackwell.

Earl, J., Martin, A., McCarthy, J.D. and Soule. S. (2004). The use of newspaper data in the study of collective action. Annual Review of Sociology, 30, 65-80.

Erder, S. and Incioglu, N. (2008). Türkiye'de yerel politikanın yükselişi: İstanbul Büyüksehir Belediyesi örnegi, 1984-2004. İstanbul: İstanbul Bilgi Üniversitesi.

Esaiasson, P. (2014). NIMBYism-A re-examination of the phenomenon. Social Science Research, 48, 185-195.

Futrell, R., and Simi, P. (2004). Free spaces, collective identity, and the persistence of us white power activism. Social Problems, 51(1), 16-42.

Gamson, W. A. (1990). The strategy of social protest. Homewood, IL: Dorsey. (Original work published 1975)

Gemici, K. (2003). Spontaneity in social protest: April 2001 shopkeeper protests in Turkey. Retrieved from https:// escholarship.org/uc/item/9nh9g6gt

Giugni, M. (Ed.). (2004). Social protest and policy change: Ecology, antinuclear, and peace movements in comparative perspective. Lanham, MD: Rowman and Littlefield.

Goodwin, J. and Jasper, J. M. (2004). Rethinking social movements: structure, culture, and emotion. Lanham, MD: Rowman \& Littlefield. 
Gould, V. R. (1995). Insurgent identities: class, community, and protest in Paris from 1848 to the Commune. Chicago: University of Chicago Press.

Graaff, M. B. and Bröer, C. (2019). Governance and risk in everyday life: depoliticization and citizens' experiences of cell site deployment in the Netherlands and Southern California. Journal of Risk Research. DOI: 10.1080/13669877.2018.1501596

Keck, M., E. and Sikkink, K. (1999). Transnational advocacy networks in international and regional politics. International Social Science Journal, 51(1), 89-101.

Kitschelt, H. (1986). Political opportunity structures and political protest: anti- nuclear movements in four democracies. British Journal of Political Science, 16(1), $57-85$.

Konda. (2013). Gezi report: public perception of the Gezi Protests. Who were the people at the Gezi Park? Retrieved from http://www.konda.com.tr/en/raporlar/KONDA_ Gezi_Report.pdf

Koopmans, R. and Rucht, R. (2002). Protest event analysis. In B. Klandermans and S. Staggenborgeds. Methods of social movement research. Minneapolis: University of Minnesota.

Krackhardt, D. (1992). The strength of strong ties: the importance of philos in organizations. In N. Nohria and R. G. Eccles (Eds.). Networks and organizations: structure, form and action. (pp. 216-239). Boston: Harvard Business School.

Krackhardt, D. (1994). Graph theoretical dimensions of informal organizations. In K. Carley, M. Prietula (Eds.). Computational organizational theory (pp. 89-111). Hillsdale, NJ, US: Lawrence Erlbaum, Hillsdale, NJ.

Kriesi, H. (2004). Political context and opportunity. In D. A. Snow, S. A. Soule, and H. Kriesi (Eds.). The Blackwell Companion to social movements (pp. 67-90). Malden, MA: Blackwell.

Lamertz, K. (2009). On the topography of shared organizational identity meanings in social networks. In S. Carayannopoulos: Proceedings of the Annual Conference of ASAC, 2009 (Organization Theory Division), Niagara Falls, ON.

Leighley, J. (1996). Group membership and the mobilization of political participation. The Journal of Politics, 58(2), 447-463.

Luders, J. (2006). The economics of movement success: business responses to civil rights mobilization. American Journal of Sociology, 111(4), 963-998.

McAdam, D. (1996). Conceptual origins, current problems, future directions. In D. McAdam, J. D. McCarthy, and M. N. Zald (Eds.). Comparative perspectives on social movements. political opportunities, mobilizing structures and cultural framing (pp. 23-40). Cambridge: Cambridge University.
McAdam, D. and Snow, D. (2010). Outcomes and impacts. In D. A. Snow and D. McAdam (Eds.) Readings on social movements: origins, dynamics and outcomes. New York: Oxford University.

McCarthy, J. D. and Zald., M. N. (1977). Resource mobilization and social movements: a partial theory. American Journal of Sociology, 82(6), 1212-1241.

Önge, S. T. (2007). Spatial representation of power: making the urban space of Ankara in the early republican period. Politica, 306, 21.

Passy, F. (2003). Social networks matter but how? In M. Diani and D. McAdam (Eds.). Social movements and networks: relational approaches to collective action (pp. 21-48). Oxford: Oxford University.

Passy, F. and Giugni, M. (2001). Social networks and individual perceptions: explaining differential participation in social movements. Sociological Forum, 16(1), 123-153.

Polletta, F. and Jasper, J. (2001). Collective identity and social movements. Annual Review of Sociology, 27, 283-305.

Provan, K., Fish, A., and Joerg, S. (2007). Interorganizational networks at the network level: a review of the empirical literature on whole networks. Journal of Management, 33(3), 479-516.

Ragin, C. C. (2008). Redesigning social inquiry: fuzzy sets and beyond. Chicago, IL: University of Chicago.

Ragin, C., C. and Sedziaka, A. (2013). QCA and Fuzzy Set applications to social movement research. In D. A. Snow, D. Della Porta, B. Klandermans and D. McAdam (Eds.). The Wiley-Blackwell Encyclopedia of Social and Political Movements. Wiley-Blackwell.

Rihoux, B. and Lobe, B. (2009). The case of qualitative comparative analysis (QCA): adding leverage for cross-case comparison. In D. Byrne and C. C. Ragin (Eds.). The Sage handbook of case-based methods (pp. 222-242). Thousand Oaks, CA: Sage.

Rojas, F. (2006). Social movement tactics, organizational change and the spread of African-American studies. Social Forces, 84(4), 2147-2166.

Rosenthal, N. and Schwartz, M. (1989). Spontaneity and democracy in social movements. International social movement research, 2, 33-59.

Şahin, S. Z. (2019). The urbanization policy of Turkey: an uneasy symbiosis of unimplemented policy with centralized pragmatic interventions. Turkish Studies, 20(4), 599-618.

Schively, C. (2007). Understanding the NIMBY and LULU phenomena: reassessing our knowledge base and informing future research. Journal of planning literature, 21(3), 255266.

Şeker, M., Bakış, Ç. and Dizeci, B. (2018). Innsani gelişme indeksi: ilçeler. İstanbul: INGEV. 
Sewell, W. H. (2001). Space in contentious politics. In R. Aminzade, J. Goldstone, D. McAdam, E. Perry, W. Sewell, S. Tarrow, et al. (Authors), Silence and voice in the study of contentious politics (pp. 51-88). Cambridge: Cambridge University.

Siegel, D. A. (2009). Social networks and collective action. American Journal of Political Science 53(1), 122-138.

Snow, D., A., and Moss, D. M. (2014). Protest on the fly: toward a theory of spontaneity in the dynamics of protest and social movements. American Sociological Review, 79(6), $1122-1143$.
Tankut, G. (1993). Bir başkentin imarı: Ankara, 1929-1939. İstanbul: Anahtar Kitaplar.

Tekeli, İ. (1982). Başkent Ankara'nın öyküsü. Ankara: Turhan Kitabevi.

Tilly, C. (1978). From mobilization to revolution. Reading, MA: Addison-Wesley.

World Values Survey.(2012). http://www.worldvaluessurvey. org/WVSOnline.jsp adresinden erişildi.

Zhao, D. (1998). Ecologies of social movements: student mobilization during the 1989 prodemocracy movement in Beijing. American Journal of Sociology, 103, 1493-1529. 